\title{
Involvement of theca cells and steroids in the regulation of granulosa cell apoptosis in rabbit preovulatory follicles
}

\author{
G. Maillet, A. Benhaïm, H. Mittre and C. Féral \\ Laboratoire de Biochimie, UPRES EA 2608, USC INRA, CHU Côte de Nacre, \\ Université de Caen, 14032 Caen Cedex, France
}

Follicular atresia is characterized by a rapid loss of granulosa cells and, to a lesser extent, theca cells, via apoptosis. The aim of this study was to investigate the possible involvement of theca cell secretions in the regulation of apoptosis of rabbit granulosa cells. The annexin- $\mathrm{V}$ binding method based on externalization of phosphatidylserine to the outer layer of plasma membrane during apoptosis was used to detect apoptotic granulosa cells in flow cytometry. Regulation of apoptosis of granulosa cells was studied in three different culture systems: (i) isolated cultured granulosa cells, (ii) granulosa cells obtained from cultured preovulatory follicles and (iii) granulosa cells co-cultured with theca cells. The results of this study indicate that: (i) the rate of apoptosis of granulosa cells was significantly reduced when granulosa cells were co-cultured with theca cells or obtained from cultured preovulatory follicles in comparison with isolated cultured granulosa cells; (ii) FSH exerts its anti-apoptotic effect only on granulosa cells issued from cultured preovulatory follicles; (iii) ovarian steroids do not affect the percentage of isolated apoptotic granulosa cells; and (iv) the occurrence of an apoptotic process in rabbit theca cells could be upregulated in vitro by hCG and an analogue of the gonadotrophin second messenger cAMP. The results of this study indicate that in rabbits (i) steroids were ineffective in vitro in protecting isolated granulosa cells against apoptosis in comparison with observations in vivo in rats, and (ii) the presence of theca cells was efficient to reduce granulosa cell apoptosis but not sufficient to allow the anti-apoptotic effect of gonadotrophins observed in cultured follicles.

\section{Introduction}

During the course of ovarian development, only a small proportion of follicles ovulate; the majority are eliminated from the ovary by atresia (Hirshfield and Midgley, 1978). This process is essential and maintains a constant cell mass and homeostasis of the adult ovary. Degenerative changes in granulosa cells are the first morphologically recognizable sign of follicular atresia, and it is well known that apoptosis is the underlying event associated with the granulosa cell death (Hughes and Gorospe, 1991). Whether theca cells undergo apoptosis is controversial. It was previously understood that theca cells persisted in the atretic follicles and were incorporated into the interstitium; however, Hurwitz and Adashi (1992) demonstrated that theca cells are eliminated from the ovary in the same manner as granulosa cells. Indeed, studies in vivo show that apoptotic cell death occurs in theca interna of avian (Tilly et al., 1991), pig (Tilly et al., 1992a), rat (Palumbo and Yeh, 1994) and bovine atretic follicles (Isobe and Yoshimura, 2000; Yang and Rajamahendran, 2000). When apoptosis occurs in theca cells it always

Email: maillet.geraldine@caramail.com occurs in the later stages of follicular atresia and at a considerably lower rate than that of granulosa cells (Palumbo and Yeh, 1994; Logothetopoulos et al., 1995).

Whether a follicle ovulates or undergoes atresia is determined by the balance of signals that the theca and granulosa cells receive. Signals, including gonadotrophin hormones $(\mathrm{LH}, \mathrm{FSH})$, other paracrine signalling molecules, such as steroid hormones (androgens and oestrogens), and growth factors, regulate the synchronized patterns of granulosa cell proliferation and cell death (McGee et al., 1998). Apoptosis of granulosa cells is mainly regulated by gonadotrophins, as demonstrated in vivo in rats (Billig et al., 1994) or in vitro in intact follicle culture systems (Chun et al., 1994, 1996; Kaipia et al., 1996). When granulosa cells were isolated, FSH was ineffective at inducing apoptosis in rats (Aharoni et al., 1995), whereas it attenuated apoptosis in pigs (Guthrie et al., 1998) and cattle (Yang and Rajamahendran, 2000; Hu et al., 2001). In a comparative study, Maillet et al. (2002) found that the sensitivity of isolated rabbit granulosa cells to apoptosis was different from that of granulosa cells obtained from cultured intact follicles. This finding indicates that the regulation of apoptosis in rabbit granulosa cells may require paracrine interactions within the follicle. 
In the present study, a co-culture system was used to analyse the role of theca cells in the regulation of apoptosis of granulosa cells in vitro, and to determine the conditions that induce apoptosis in theca cells in vitro.

\section{Materials and Methods}

\section{Reagents}

Equine chorionic gonadotrophin (eCG) was purchased from Chrono-Gest (Intervet, Paris). Eagles' minimum essential medium (MEM), fetal calf serum (FCS), trypsineEDTA and penicillin and streptomycin were purchased from Eurobio (Les Ulys). BSA, Hepes, EGTA, sucrose, collagenase (type II), hyaluronidase (type II), protease (type XIV), dibutyryl cAMP (dbcAMP) and specific antibodies for radioimmunoassay of oestradiol and progesterone were obtained from Sigma Chemical (St Quentin Fallavier). Purified ovine FSH (USDA-o-FSH20, $4.453 \mathrm{iu} \mathrm{mg}^{-1}$ ) was obtained through the National Hormone and Pituitary Program (NIDKK) and A. F. Parlow. hCG was obtained from Organon (Serifontaine). The narcotic Embutramide T61 was provided by Distrivet (Paris). The annexin $\mathrm{V}$-fluorescein isothiocyanate (annexin V-FITC) kit was a Boerhinger-Ingelheim kit supplied by Coger (Paris).

\section{Animals and treatments}

HY female white rabbits, aged 10-12 weeks (Elevage Gastebled, Hottot Les Bagues), were housed individually for about 2 weeks on a $14 \mathrm{~h}$ light (06:00-20:00 h):10 h dark photoperiod with standard rabbit food and water available ad libitum. Animals were bred under standard conditions according to the instructions of Ministère de l'Agriculture et de la Pêche-Service Santé Animale (France).

The development of preovulatory follicles was induced in these rabbits by i.m. injection of 200 iu eCG on 2 consecutive days. The animals were killed by intracardiac injection of $2 \mathrm{ml}$ of a narcotic (Embutramide T61) 4 days after the first injection of eCG.

The ovaries were excised and placed in MEM containing $20 \mathrm{mmol}$ Hepes $\mathrm{I}^{-1}$, 50 iu penicillin $\mathrm{ml}^{-1}$, $50 \mu \mathrm{g}$ streptomycin $\mathrm{ml}^{-1}$ and $0.1 \%$ BSA (MEM-0.1\% BSA). The follicles were extirpated out (those containing clotted blood were discarded) and cleared of interstitial tissue under a stereomicroscope.

\section{Collection of cells}

Dispersed granulosa cells and theca cells were obtained as described by Féral et al. (1995). Briefly, follicles were cut in half in MEM-0.1\% BSA containing $6.8 \mathrm{mmol} \mathrm{EGTA}^{-1}$ and incubated for $10 \mathrm{~min}$. Released granulosa cells and follicles were centrifuged together for $10 \mathrm{~min}$ at $300 \mathrm{~g}$ and resuspended in MEM-0.1\% BSA containing $0.5 \mathrm{mmol}$ sucrose $\mathrm{I}^{-1}$ and $1.8 \mathrm{mmol}$ EGTA $\mathrm{I}^{-1}$ for $5 \mathrm{~min}$ before centrifugation again at $300 \mathrm{~g}$ for $10 \mathrm{~min}$. Granulosa cells were gently scraped from the theca with a microspatula under a dissecting microscope. For co-culture experiments, follicular walls were cut into four and washed three times in MEM-0.1\% BSA before being placed in a cell culture insert. For culture of isolated theca cells, follicular walls were minced with iris scissors and incubated in MEM- $0.1 \%$ BSA containing $0.1 \%(\mathrm{w} / \mathrm{v})$ collagenase and $0.1 \%(\mathrm{w} / \mathrm{v})$ hyaluronidase for $10 \mathrm{~min}$ at $37^{\circ} \mathrm{C}$. After the addition of $5 \mathrm{ml} \mathrm{MEM-}$ $0.1 \%$ BSA, pieces of tissue were centrifuged at $300 \mathrm{~g}$ for $30 \mathrm{~s}$. The supernatant consisting of the remaining granulosa cells was discarded. Subsequently, pieces of theca were dissociated in MEM-0.1\% BSA containing $0.2 \%(\mathrm{w} / \mathrm{v})$ hyaluronidase and $0.1 \%(\mathrm{w} / \mathrm{v})$ protease for $10 \mathrm{~min}$ at $37^{\circ} \mathrm{C}$. Histological and biochemical analyses indicated that the level of contamination of theca cells with granulosa cells was $<1 \%$ (Féral et al., 1990). The dispersed granulosa and theca cells were pelleted separately by centrifugation at $300 \mathrm{~g}$ for $10 \mathrm{~min}$.

\section{Culture of granulosa and theca cells}

After two washes in MEM-0.1\% BSA, granulosa or theca cells were plated in serum-free medium with or without gonadotrophin or steroids at the density of $3 \times 10^{5}$ cells per well in $1 \mathrm{ml}$ in Falcon 24-well tissue culture plates for $72 \mathrm{~h}$. Steroids were dissolved in ethanol. The final concentration of ethanol had no effect on the percentage of granulosa cell apoptosis. After culture, floating and attached cells were collected. Adherent cells were washed twice with warm PBS without $\mathrm{Ca}^{2+}$ or $\mathrm{Mg}^{2+}$ and treated for 5 min at $37^{\circ} \mathrm{C}$ with PBS containing $0.5 \mathrm{~g}$ trypsin $\mathrm{I}^{-1}$ and $0.2 \mathrm{~g}$ EDTA $\mathrm{I}^{-1}$. When adherent cells became round as a result of trypsin action, they were gently agitated until all cells were detached from the plate. Trypsine activity was stopped by the addition of medium supplemented with $5 \%$ FCS, and cells were treated for apoptosis analysis.

\section{Culture of follicles}

Preovulatory follicles were dissected from ovaries as described above. Six follicles per treatment group were placed in Falcon 24-well tissue culture plates in serumfree conditions with or without gonadotrophin treatment and incubated for $72 \mathrm{~h}$. After culture, the follicles of each treatment group were washed in MEM-0.1\% BSA and dispersed granulosa and theca cells were obtained as described above. Dispersed granulosa and theca cells were washed in cold PBS before they were assessed for apoptosis.

\section{Co-culture}

A co-culture system was used to determine the effects of theca cells on apoptosis of granulosa cells. Briefly, 
dispersed granulosa cells obtained as described above were plated at the density of $3 \times 10^{5}$ cells per well in a Falcon 24-well tissue culture plate. A cell culture insert (0.1 $\mu \mathrm{m}$ pore size for 24 -well format, Falcon) containing pieces of theca was placed in each well above plated granulosa cells without any direct contact. Theca pieces placed in the culture insert were equivalent to eight preovulatory follicles.

Co-culture was conducted in serum-free conditions with or without gonadotrophins for $72 \mathrm{~h}$. Control wells containing granulosa cells only and wells containing granulosa cells treated with $10^{-7} \mathrm{~mol}$ androstenedione $I^{-1}$ were used for each experiment. At the end of culture, granulosa cells were collected by trypsinization as described above.

\section{Detection of apoptosis}

On the basis of externalization of phosphatidylserine to the outer layer of plasma membrane during apoptosis, apoptotic cells were quantified according to the manufacturer's instructions for annexin V-FITC kit as described by Maillet et al. (2002). After two washes with binding buffer, annexin V-FITC $\left(3 \mu \mathrm{g} \mathrm{ml}^{-1}\right)$ and propidium iodide (PI) (400 ng ml-1) were added to the cell suspension $\left(3 \times 10^{5}\right.$ cells per $\left.500 \mu \mathrm{l}\right)$ and incubated for $10 \mathrm{~min}$ in the dark. Granulosa and theca cells were analysed during the hour after incubation in a fluorescence-activated cell sorter (FACScalibur, Becton-Dickinson, Sunnyvale, CA) using a $15 \mathrm{~mW}$ argon laser emitting light at 488nm. The following settings were used: $475 \mathrm{~V}$ on photomultiplier tubes both for fluorochrome one (FL1) (FITC) and fluorochrome two (FL2) (PI). Because fluoresence intensity of FL1 could be detected on FL2 photomultiplier tubes and vice-versa, a compensation setting (FL1-\%FL2) was used. Compensation settings FL1-\%FL2 and FL2$\%$ FL1 were 1.0 and $32.5 \%$, respectively. Data analysis was performed with the Cell Quest software (BectonDickinson). Ten thousand cells were analysed in each treatment group.

\section{Production of progesterone and oestradiol}

Concentrations of oestradiol and progesterone in culture media of granulosa cells were quantified by radioimmunoassay using specific antibodies as described by Benhaïm et al. (1987). Oestradiol was measured after extraction with five volumes of ether, whereas progesterone was measured directly in the culture media. The sensitivity of the assay for oestradiol was $3 \mathrm{pg}$ per well and the intra- and interassay coefficients of variation were $<4$ and $10 \%$, respectively. The sensitivity of the assay for progesterone was 5 pg per well and the intra- and interassay coefficients of variation were 5 and $9 \%$, respectively. The results are expressed as steroids secreted by $10^{4}$ cells during $72 \mathrm{~h}$ of culture.

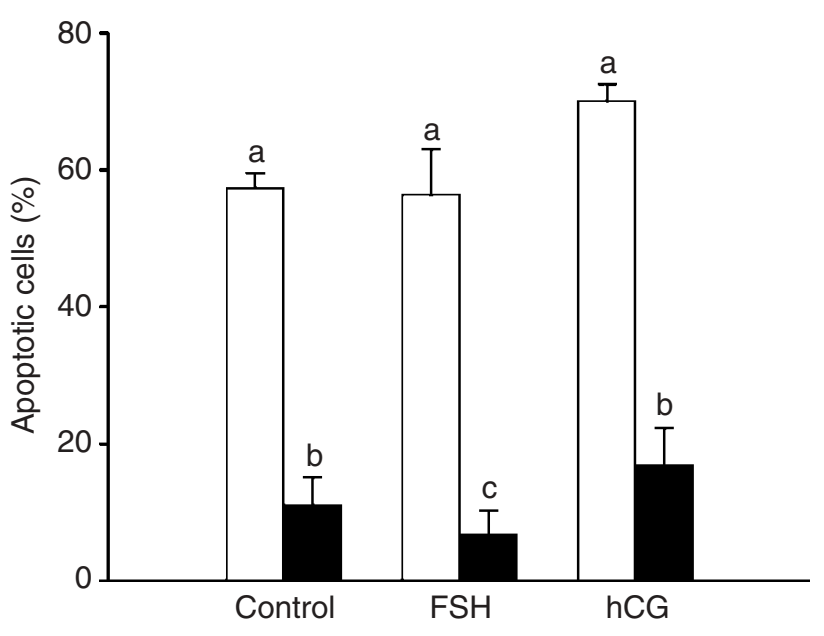

Fig. 1. Effects of FSH $\left(5 \mathrm{ng} \mathrm{ml}^{-1}\right)$ and hCG $\left(10 \mathrm{miu} \mathrm{ml}^{-1}\right)$ on

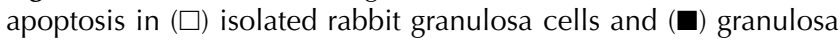
cells scraped from rabbit preovulatory follicles both cultured for $72 \mathrm{~h}$ in serum-free conditions. Values are mean \pm SEM of three experiments performed in triplicate for isolated cells or a single well for cultured follicles. Values with different superscripts are significantly different $(P<0.05)$.

\section{Statistical analysis}

Data regarding the production of steroids and the percentage of apoptotic cells were expressed as the means \pm SEM of three experiments. In each experiment, granulosa cells were pooled from the ovaries of two rabbits, and each treatment was performed in triplicate for isolated cells or in a single well for cultured follicles. Data regarding the percentage of apoptotic cells obtained after annexin $\mathrm{V}$ binding analysis needed an arcsin transformation to obtain a normal distribution. Differences between treatment groups (raw data for the production of steroids or transformed data for the percentage of apoptotic cells) were assessed by a twoway ANOVA followed by Fisher's test and considered to be significant at $P<0.05$.

\section{Results}

\section{Involvement of theca in apoptosis of granulosa cells}

When cultured in isolation in serum-free medium, a large number of granulosa cells were apoptotic (57 $\pm 2 \%$ ). Addition of FSH and hCG had no significant effect on the percentage of apoptotic granulosa cells (Fig. 1). Granulosa cells were viable after this $72 \mathrm{~h}$ culture period because cell mortality determined by $\mathrm{PI}$ uptake was very low in the control cells $(2.67 \pm 0.57 \%$ dead cells) and did not change regardless of the gonadotrophin treatment $(2.25 \pm 0.59 \%$ dead cells with $5 \mathrm{ng}$ FSH ml $\mathrm{ml}^{-1}, 2.97 \pm 0.45 \%$ dead cells with $10 \mathrm{miu}$ hCG $\mathrm{ml}^{-1}$ ). When granulosa cells were isolated from follicles cultured in serum-free medium, the analysis 


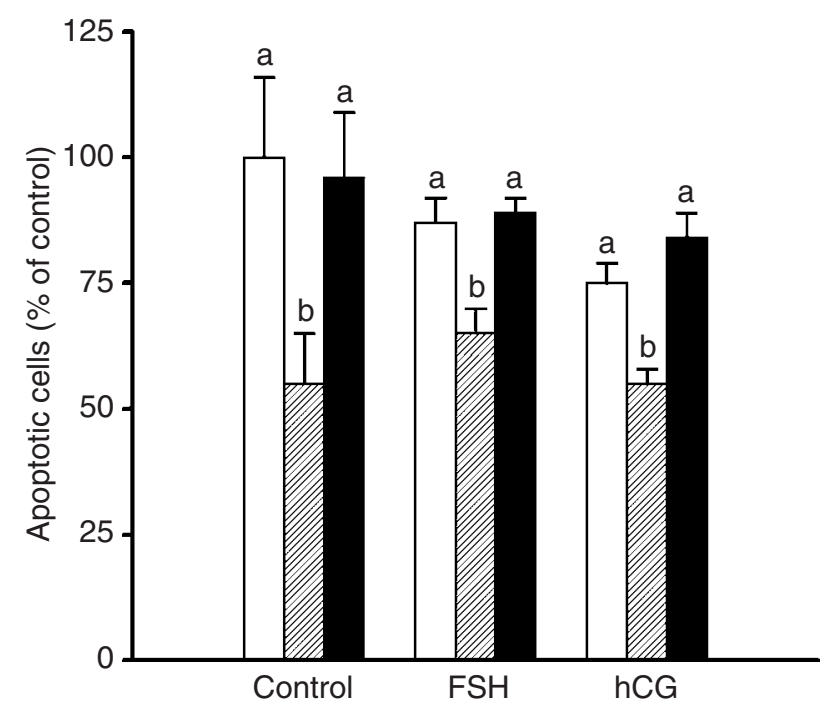

Fig. 2. Effects of FSH $\left(5 \mathrm{ng} \mathrm{ml}^{-1}\right)$ and hCG $\left(10 \mathrm{miu} \mathrm{ml}^{-1}\right)$ on apoptosis in isolated rabbit granulosa cells $(\square)$ cultured for $72 \mathrm{~h}$ in serum-free conditions in the presence of (絲) theca cells or (ם) androstenedione $\left(10^{-7} \mathrm{~mol} \mathrm{I}^{-1}\right)$. Values are the mean \pm SEM of three experiments performed in triplicate. Control $=37 \pm 6 \%$ apoptotic cells. Values with different superscripts are significantly different $(P<0.05)$.

of phosphatidylserine exposure showed $11 \pm 4 \%$ of apoptotic granulosa cells and the addition of $\mathrm{FSH}$ in culture medium resulted in a significant decrease in the percentage of apoptotic granulosa cells. Addition of hCG did not affect the number of apoptotic cells (Fig. 1).

This first experiment illustrates the role of follicular integrity on apoptosis of granulosa cells. As oestradiol is the main steroid present in preovulatory follicles, its effect on apoptosis of cultured granulosa cells was examined. It was noted that increasing doses $\left(10^{-12}\right.$ to $10^{-7} \mathrm{~mol} \mathrm{I}^{-1}$ ) of oestradiol did not affect the percentage of apoptotic granulosa cells (data not shown). The effect of increasing doses $\left(10^{-10}\right.$ to $\left.10^{-7} \mathrm{~mol} \mathrm{I}^{-1}\right)$ of progesterone on apoptosis of granulosa cells was also examined, and this steroid did not affect apoptosis of rabbit granulosa cells (data not shown).

A co-culture system that allowed the modulation of granulosa cell apoptosis to be studied in the presence or absence of theca cells was used to investigate the involvement of theca cells in regulation of granulosa cell apoptosis. In the presence of theca, granulosa cell death was significantly decreased (1.6-fold versus control) (Fig. 2). When gonadotrophins FSH or hCG were added to the co-culture, the percentage of apoptotic granulosa cells did not change (Fig. 2).

Wells containing granulosa cells only were treated with $10^{-7}$ mol androstenedione $\mathrm{I}^{-1}$ to determine whether the effect of theca cells on granulosa cell death occurred via androgens produced by theca cells. It was noted that
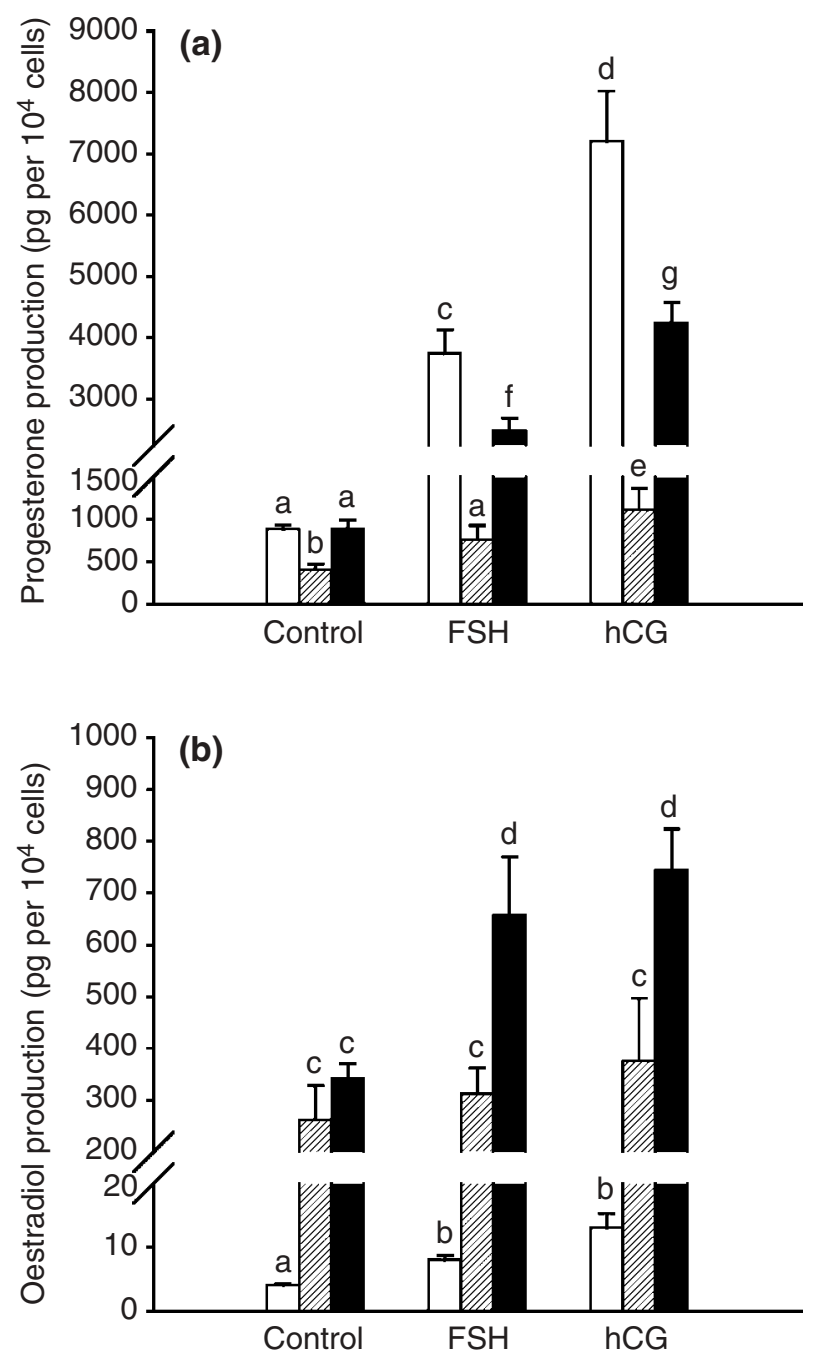

Fig. 3. Effects of $\mathrm{FSH}\left(5 \mathrm{ng} \mathrm{ml}^{-1}\right)$ and hCG $\left(10 \mathrm{miu} \mathrm{ml} \mathrm{m}^{-1}\right)$ on (a) progesterone and (b) oestradiol production by isolated rabbit granulosa cells $(\square)$ cultured for $72 \mathrm{~h}$ in serum-free conditions in the presence of (距) theca cells or $(\boldsymbol{\square})$ androstenedione $\left(10^{-7} \mathrm{~mol}\right.$ $\mathrm{I}^{-1}$ ). Values are the mean \pm SEM of three experiments performed in triplicate. Values with different superscripts are significantly different $(P<0.05)$.

this dose of androstenedione did not affect granulosa cell apoptosis either alone or when granulosa cells were treated with gonadotrophins (Fig. 2). The addition of $10^{-8}$ and $10^{-6} \mathrm{~mol}$ androstenedione $\mathrm{I}^{-1}$ confirm that this steroid did not affect the percentage of apoptotic granulosa cells in vitro (data not shown).

Progesterone and oestradiol production by granulosa cells co-cultured with theca cells

In parallel to the study of apoptosis, the production of progesterone and oestradiol by granulosa cells during $72 \mathrm{~h}$ of culture was measured under different conditions (Fig. 3). 
Granulosa cells produced 900 pg progesterone per $10^{4}$ cells in serum-free medium (Fig. 3a). Co-culture with theca inhibited progesterone production, whereas the addition of androstenedione did not significantly affect progesterone accumulation. When granulosa cells were treated with $5 \mathrm{ng} \mathrm{FSH} \mathrm{ml}{ }^{-1}$ or 10 miu hCG ml m $^{-1}$, progesterone production was increased 4.3- and eightfold, respectively, compared with control cells. Coculture of granulosa cells with theca in the presence of FSH significantly reduced the $\mathrm{FSH}$-induced progesterone production, as did hCG. Treatment of granulosa cells with both androstenedione and FSH or hCG induced a 1.5or 1.7-fold decrease in $\mathrm{FSH}$-induced and hCG-induced progesterone production, respectively (Fig. 3a).

Granulosa cells produced very little oestradiol (4 pg per $10^{4}$ cells) in serum-free medium (Fig. 3b). This production was positively regulated by FSH and hCG (2- and 3.3-fold increase, respectively). Co-culture of granulosa cells with theca induced a 65 -fold increase in oestradiol accumulation. Theca-induced oestradiol production was mimicked by treatment of granulosa cells with $10^{-7} \mathrm{~mol}$ androstenedione $\mathrm{I}^{-1}$ (Fig. 3b). The addition of gonadotrophins to the co-culture did not affect theca-induced oestradiol production, but did induce a twofold increase in androstenedione-stimulated oestradiol production by isolated granulosa cells (Fig. 3b).

\section{Regulation of apoptosis of theca cells}

When preovulatory follicles were cultured in serumfree medium for $72 \mathrm{~h}$, the percentage of apoptotic theca cells did not change significantly in the presence or absence of $5 \mathrm{ng} \mathrm{FSH} \mathrm{ml}{ }^{-1}$ or 10 miu hCG ml-1 (data not shown).

Isolated theca cells were cultured for $72 \mathrm{~h}$ in medium with increasing doses $\left(0-50 \mathrm{miu} \mathrm{m}^{-1}\right)$ of hCG to determine whether apoptosis of theca cells could be induced in vitro (Fig. 4). In the absence of serum, treatment with hCG induced a weak, but significant, increase in the percentage of apoptotic theca cells. The addition of serum in culture medium induced a twofold decrease in apoptotic theca cells and addition of hCG resulted in a slight increase in this rate (Fig. 4).

The effect of dbcAMP, an analogue of gonadotrophin second messenger CAMP on apoptosis of theca cells was determined (Fig. 5). A low $\left(0.1 \mathrm{mmol} \mathrm{I}^{-1}\right)$ as well as a high dose of dbcAMP $\left(5 \mathrm{mmol} \mathrm{I}^{-1}\right)$ induced an increase in the rate of apoptosis without change in the percentage of dead cells (PI + cells) (data not shown) excluding a possible cytotoxic effect of dbcAMP on theca cells. A low dose of dbcAMP induced a twofold increase in progesterone production by theca cells $(P<0.05 \mathrm{com}-$ pared with control), whereas treatment with $5 \mathrm{mmol}$ dbcAMP $\left.\right|^{-1}$ resulted in a 20 -fold stimulation of progesterone secretion $(P<0.001$ compared with control) (data not shown).

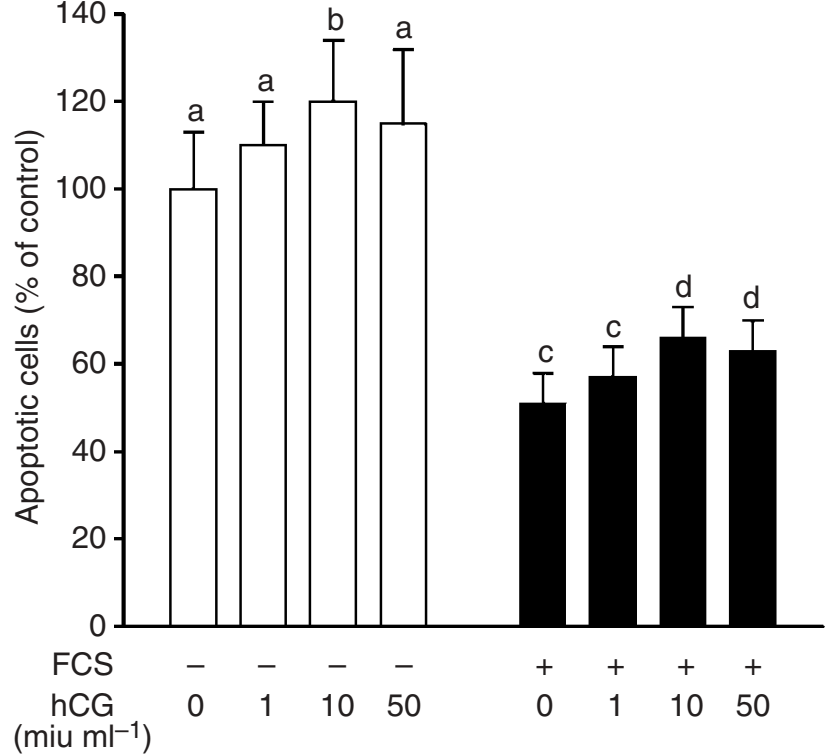

Fig. 4. Effect of increasing doses of hCG on apoptosis in isolated rabbit theca cells cultured for $72 \mathrm{~h}$ in the $(\square)$ absence or presence of fetal calf serum (FCS). Values are the mean \pm SEM of three experiments performed in triplicate. Values with different superscripts are significantly different $(P<0.05)$.

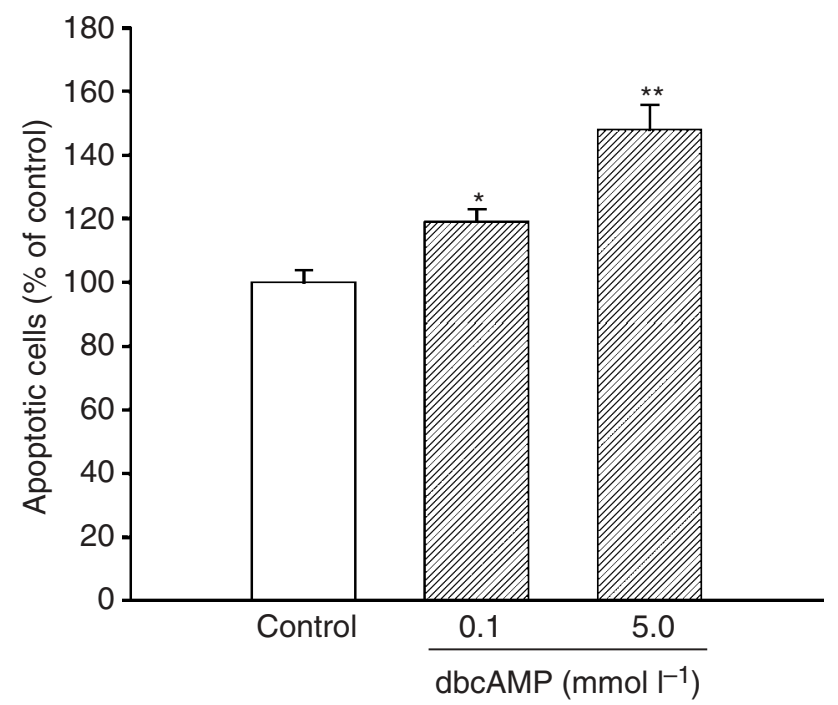

Fig. 5. Effect of dbcAMP on apoptosis in isolated rabbit theca cells cultured for $72 \mathrm{~h}$ in serum-containing medium. Values are the mean \pm SEM of three experiments performed in triplicate. Control $=25 \pm 3 \%$ apoptotic cells. $* P<0.05$ and ${ }^{* *} P<0.01$ compared with the control value.

\section{Discussion}

In the present study, the use of different culture models provided an opportunity to investigate the involvement of theca cells in granulosa cell apoptosis in the rabbit ovary and demonstrated that apoptosis could be induced and regulated in theca cells in vitro. 
Maillet et al. (2002) reported that the regulation of apoptosis in granulosa cells appears to require paracrine interactions within the follicle. The present study used a co-culture system to show that theca cells could reduce the rate of granulosa cell death. This anti-apoptotic effect of theca cells was not sufficient to mimic the protective effect exerted in the follicle in so far as the rate of apoptosis of granulosa cells obtained from cultured follicle was lower than that of granulosa cells co-cultured with theca. The disruption of granulosa cellto-cell contacts in cultured isolated cells could provide an explanation for these findings. Indeed, Peluso (1997) showed that single granulosa cells are more likely to undergo apoptosis in vitro when compared with clumps of granulosa cells.

In the present study, treatment of granulosa cells with androstenedione or oestradiol had no effect on apoptosis induced by serum deprivation regardless of the dose. Therefore, the observed protective effect of theca on apoptosis of granulosa cells could not be due to a direct or indirect effect of the ovarian steroids. In vivo, an apoptotic effect of androgens has been reported, whereas oestradiol prevented ovarian apoptotic DNA degradation in hypophysectomized rats (Billig et al., 1993). In vitro, Murdoch (1998) demonstrated an inhibition of oxidative stress-induced apoptosis by oestradiol in pig ovarian tissues. Thus, the results of the present study in vitro indicate that, oestradiol and androstenedione have an indirect effect on apoptosis of granulosa cells in vivo.

Progesterone is an important ovarian steroid which is required as a survival factor by many types of cell, in particular human granulosa cells (Makrigiannakis et al., 2000). In the present study, the percentage of apoptotic rabbit granulosa cells did not change with increasing doses of progesterone. This finding could be explained by the fact that expression of progesterone receptors in rabbit granulosa cells is weak before the $\mathrm{LH}$ surge (Iwai et al., 1991). In contrast, the anti-apoptotic effect of progesterone on human granulosa cells was exerted on cells from patients undergoing IVF and thus was obtained after LH surge.

However, co-culture of rabbit granulosa cells with theca or androstenedione inhibited progesterone production. This result is in agreement with inhibition of progesterone production by androgen observed in human and pig cultured granulosa cells (Batta et al., 1980; Lischinsky et al., 1983). Androgens inhibit progesterone synthesis via the inhibition of conversion of pregnenolone to progesterone (Evans et al., 1984).

Several factors produced by theca other than steroids could be involved in the protective effect of theca cells on granulosa cell death. For example, keratinocyte growth factor produced by theca cells (Parrott et al., 1994) suppresses apoptosis in cultured rat preantral follicles (McGee et al., 1999). Transforming growth factor alpha (TGF $\alpha$ ) and epidermal growth factor, which are produced by theca-interstitial layer follicles (Kudlow et al., 1987; Skinner et al., 1987), were shown to inhibit the spontaneous onset of apoptotic DNA cleavage of granulosa cells obtained from rat preovulatory follicles (Tilly et al., 1992b).

The present study demonstrated that the presence of theca was not sufficient to allow the anti-apoptotic effect of $\mathrm{FSH}$, indicating that anti-apoptotic paracrine factors are produced in the follicle but not by theca cells. Growth differentiation factor 9 (GDF-9) is a protein of the TGF $\beta$ /activin superfamily produced by oocytes in several species (Bodensteiner et al., 1999). GDF-9 stimulates follicle growth, but its potential role in the regulation of granulosa cell death remains to be elucidated (Erickson and Shimasaki, 2001). However, the action of FSH may require the presence of basal lamina in cultured intact follicles. Indeed, laminin, a protein which constitutes about $35 \%$ of total basement membrane proteins, was shown to inhibit apoptosis of rat and sheep granulosa cells (Aharoni et al., 1996; Huet et al., 2001).

The present study showed that apoptosis could be induced in vitro in isolated rabbit theca cells that had been cultured in serum-free medium. Foghi et al. (1997) demonstrated that apoptosis of isolated theca cells in vitro could be induced in rat preantral follicles, only in combined treatment with TGF $\alpha$ and TGF $\beta$ and not under serum-free conditions. These discrepancies could be due to different follicular stage studied, in addition to the different culture conditions.

The anti-apoptotic effect of gonadotrophins was shown in vitro in whole rat preovulatory follicles (Chun et al., 1994; Eisenhauer et al., 1995), but studies on isolated theca cells have not been performed. The present study failed to demonstrate any effect of hCG on apoptosis of theca cells in intact cultured preovulatory follicles, whereas in isolated rabbit theca cells, $10 \mathrm{miu}$ hCG $\mathrm{ml}^{-1}$ resulted in a slight increase in apoptosis. This paradoxical effect is in agreement with the study of Aharoni et al. (1995) in which an apoptotic effect of hCG on preovulatory rat granulosa cells cultured in serum-free conditions was reported.

However, in the present study, dbcAMP stimulated apoptosis in isolated theca cells of rabbit preovulatory follicles in vitro without modifying theca cell viability, excluding a cytotoxic effect of dbcAMP. This analogue of cAMP was shown to induce apoptosis particularly in rat granulosa cells from preovulatory follicles (Aharoni et al., 1995) and in human granulosa cells (Makrigiannakis et al., 1999). A similar effect of dbcAMP was also observed in our laboratory in cultured granulosa cells obtained from rabbit preovulatory follicles (Maillet et al., 2002). It was shown that cAMP-induced apoptosis in rat granulosa cells involved the activation of tumour suppressor gene p53 (Keren-Tal et al., 1995).

Treatment of theca cells with dbcAMP caused a simultaneous increase in apoptosis and in progesterone production as observed in rabbit granulosa cells by Maillet et al. (2002), indicating the steroidogenic and 
apoptotic processes are independent of one another, as suggested by Amsterdam et al. (1998).

In summary, the present study has shown that apoptosis could be induced and regulated in vitro in isolated rabbit theca cells. The use of a co-culture system made it possible to demonstrate that theca cells were effective in reducing rabbit granulosa cell apoptosis, and this protective effect did not appear to act via secretion of ovarian steroids. Other paracrine factors may be required for an additional inhibition of programmed cell death in the preovulatory follicles and their identification remains to be elucidated.

The authors thank V. Salaun (Haematology laboratory, $\operatorname{Pr}$ Troussard, CHU de Caen) for her assistance in the use of the flow cytometer and the National Hormone and Pituitary Program (NIDDK) and A. F. Parlow for providing purified ovine FSH. The authors would also like to thank C. Lecampion for technical laboratory assistance.

\section{References}

Aharoni D, Dantes A, Oren M and Amsterdam A (1995) cAMP-mediated signals as determinants for apoptosis in primary granulosa cells Experimental Cell Research 218 271-282

Aharoni D, Meiri I, Atzmon R, Vlodawsky I and Amsterdam A (1996) Differential effect of components of the extracellular matrix on differentiation and apoptosis Current Biology 7 43-51

Amsterdam A, Dantes A, Hosokawa K, Schere-Levy CP, Kotsuji F and Aharoni D (1998) Steroid regulation during apoptosis of ovarian follicular cells Steroids 63 314-318

Batta SK, Wentz AC and Channing CP (1980) Steroidogenesis by human ovarian cell types in culture: influence of mixing of cell types and effect of added testosterone Journal of Clinical Endocrinology and Metabolism $50274-279$

Benhaïm A, Bonnamy PJ, Papadopoulos V, Mittre H and Leymarie P (1987) In vitro action of $\mathrm{PGF}_{2 \alpha}$ on progesterone and cAMP synthesis in small bovine luteal cells Prostaglandins 33 227-239

Billig H, Furuta I and Hsueh AJW (1993) Estrogens inhibit and androgens enhance ovarian granulosa cells apoptosis Endocrinology 1332204 2212

Billig H, Furuta I and Hsueh AJW (1994) Gonadotropin-releasing hormone directly induces apoptotic cell death in the rat ovary: biochemical and in situ detection of deoxyribonucleic acid fragmentation in granulosa cells Endocrinology 134 245-252

Bodensteiner KJ, Clay CM, Moeller CL and Sawyer HR (1999) Molecular cloning of the ovine growth/differentiation factor-9 gene and expression of growth/differentiation factor-9 in ovine and bovine ovaries Biology of Reproduction 60 381-386

Chun SY, Billig H, Tilly JL, Furuta J, Tsafriri A and Hsueh AJW (1994) Gonadotropin suppression of apoptosis in cultured preovulatory follicles: mediatory role of endogenous insulin-like growth factor I Endocrinology 135 1845-1853

Chun SY, Eisenhauer KM, Minami S, Billig H, Perlas E and Hsueh AJW (1996) Hormonal regulation of apoptosis in early antral follicles: folliclestimulating hormone as a major survival factor Endocrinology 137 14471456

Eisenhauer KM, Chun SY, Billig H and Hsueh AJW (1995) Growth hormone suppression of apoptosis in preovulatory rat follicles and partial neutralization by insulin-like growth factor binding protein Biology of Reproduction 53 13-20

Erickson GF and Shimasaki S (2001) The physiology of folliculogenesis: the role of novel growth factors Fertility and Sterility 76 943-949

Evans G, Lischinsky A, Daniel SA and Armstrong DT (1984) Androgen inhibition of FSH-stimulated progesterone production by granulosa cells of prepubertal pigs Canadian Journal of Physiology and Pharmacology $62840-845$

Féral C, Reznik Y, Le Gall S, Mahoudeau J, Corvol P and Leymarie P (1990) Stimulation by hCG of ovarian inactive renin synthesis in rabbit preovulatory theca cells Journal of Reproduction and Fertility 89 407414

Féral C, Le Gall S and Leymarie P (1995) Angiotensin II modulates steroidogenesis in granulosa and theca in the rabbit ovary: its possible involvement in atresia European Journal of Endocrinology 133 747753

Foghi A, Teerds KJ, van der Donk H and Dorrington J (1997) Induction of apoptosis in rat thecal/interstitial cells by transforming growth factor $\alpha$ plus transforming growth factor $\beta$ in vitro. Journal of Endocrinology 153 169-178

Guthrie HD, Garrett WM and Cooper BS (1998) Follicle-stimulating hormone and insulin-like growth factor-I attenuate apoptosis in cultured porcine granulosa cells Biology of Reproduction 58 390-396

Hirshfield AN and Midgley JAR (1978) Morphometric analysis of follicular development in the rat Biology of Reproduction 19 606-611

Hu CL, Cowan RG, Harman RM, Porter DA and Quirk SM (2001) Apoptosis of bovine granulosa cells after serum withdrawal is mediated by Fas antigen (CD95) and Fas ligand Biology of Reproduction 64518 526

Huet C, Pisselet C, Mandon-Pepin B, Monget P and Monniaux D (2001) Extracellular matrix regulates ovine granulosa cell survival, proliferation and steroidogenesis: relationships between cell shape and function Journal of Endocrinology 169 347-360

Hughes FM and Gorospe WC (1991) Biochemical identification of apoptosis (programmed cell death) in granulosa cells: evidence for a potential mechanism underlying follicular atresia Endocrinology 129 24152422

Hurwitz A and Adashi EY (1992) At the cutting edge: ovarian follicular atresia as an apoptotic process: a paradigm for programmed cell death in endocrine tissues Molecular and Cellular Endocrinology $\mathbf{8 4}$ C19-C23

Isobe $\mathbf{N}$ and Yoshimura $\mathbf{Y}$ (2000) Localization of apoptotic cells in the cystic ovarian follicles of cows: a DNA-end labeling histochemical study Theriogenology 53 897-904

Iwai T, Fujii S, Nanbu Y, Nonogaki H, Konishi I, Mori T and Okamura H (1991) Effect of human chorionic gonadotropin on the expression of progesterone receptors and estrogen receptors in rabbit ovarian granulosa cells and the uterus Endocrinology 129 1840-1848

Kaipia A, Chun SY, Eisenhauer K and Hsueh AJW (1996) Tumor necrosis factor-alpha and its second messenger, ceramide, stimulate apoptosis in cultured ovarian follicles Endocrinology 137 4864-4870

Keren-Tal I, Suh BS, Dantes A, Lindner S, Oren M and Amsterdam A (1995) Involvement of p53 expression in cAMP-mediated apoptosis in immortalized granulosa cells Experimental Cell Research 218 283-295

Kudlow JE, Kobrin MS, Purchio AF, Twardzik DR, Hernandez ER, Asa SL and Adashi EY (1987) Ovarian transforming growth factor-alpha gene expression: immunohistochemical localization to the theca-interstitial cells Endocrinology 121 1577-1579

Lischinsky A, Evans G and Armstrong DT (1983) Site of androgen inhibition of follicle-stimulating hormone-stimulated progesterone production in porcine granulosa cells Endocrinology 113 1999-2003

Logothetopoulos J, Dorrington JH, Baily D and Stratis M (1995) Dynamics of follicular growth and atresia of large follicles during the ovarian cycle of the guinea-pig. Fate of the degenerating follicles: a quantitative study Anatomical Record 243 37-48

McGee EA, Hsu SY, Kaipia A and Hsueh AJW (1998) Cell death and survival during ovarian follicle development Molecular and Cellular Endocrinology 140 15-18

McGee EA, Chun SY, Lai S, He Y and Hsueh AJW (1999) Keratinocyte growth factor promotes the survival, growth, and differentiation of preantral ovarian follicles Fertility and Sterility 74 732-738

Maillet G, Bréard E, Benhaïm A, Leymarie $\mathbf{P}$ and Féral C (2002) Hormonal regulation of apoptosis in rabbit granulosa cells in vitro: evaluation by flow cytometric detection of plasma membrane phosphatidylserine externalisation Reproduction 123 243-251 
Makrigiannakis A, Coukos G, Christofidou-Solomidou M, Gour BJ, Radice GL, Blaschuk O and Coutifaris C (1999) N-cadherin-mediated human granulosa cell adhesion prevents apoptosis. A role in follicular atresia and luteolysis? American Journal of Pathology 154 1391-1406

Makrigiannakis A, Coukos G, Christofidou-Solomidou M, Montas S and Coutifaris C (2000) Progesterone is an autocrine-paracrine regulator of human granulosa cell survival in vitro. Annals of New York Academic Science 900 16-25

Murdoch WJ (1998) Inhibition by estradiol of oxidative stress-induced apoptosis in pig ovarian tissues Journal of Reproduction and Fertility 114 127-130

Palumbo A and Yeh J (1994) In situ localization of apoptosis in the rat ovary during follicular atresia Biology of Reproduction 51 888-895

Parrott JA, Vigne JL, Chu BZ and Skinner MK (1994) Mesenchymal-epithelial interactions in the ovarian follicle involve keratinocyte and hepatocyte growth factor production by thecal cells and their action on granulosa cells Endocrinology 135 569-575

Peluso JJ (1997) Putative mechanism through which N-cadherin-mediated cell contact maintains calcium homeostasis and thereby prevents ovarian cells from undergoing apoptosis Biochemical Pharmacology $\mathbf{5 4}$ 847-853

Skinner MK, Lobb D and Dorrington JH (1987) Ovarian thecal interstitial cells produce an epidermal growth factor-like substance Endocrinology 121 1892-1899
Tilly JL, Kowalski KI, Johnson AL and Hsueh AJW (1991) Involvement of apoptosis in ovarian follicular atresia and postovulatory regression Endocrinology 129 2799-2801

Tilly JL, Kowalski KI, Schomberg DW and Hsueh AJW (1992a) Apoptosis in atretic ovarian follicles is associated with selective decreases in messenger ribonucleic acid transcripts for gonadotropin receptors and cytochrome P450 aromatase Endocrinology 131 1670-1676

Tilly JL, Billig H, Kowalski KI and Hsueh AJW (1992b) Epidermal growth factor and basic fibroblast growth factor suppress the spontaneous onset of apoptosis in cultured rat ovarian granulosa cells and follicles by a tyrosine kinase-dependent mechanism Molecular Endocrinology 6 1942-1950

Yang MY and Rajamahendran R (2000) Morphological and biochemical identification of apoptosis in small, medium and large bovine follicle and the effects of follicle stimulating hormone and insulin-like growth factor I on spontaneous apoptosis in cultured bovine granulosa cells Biology of Reproduction 62 1209-1217

Received 2 September 2002.

First decision 20 November 2002.

Revised manuscript received 30 December 2002

Accepted 7 February 2003 